\title{
Kewenangan Biro Hukum Sekretariat Daerah Provinsi Sulawesi Tenggara dalam Penyelesaian Perkara Litigasi di Lingkungan Pemerintah Daerah
}

\author{
The Authority of Regional Secretary Legal Bureau of Southeast Sulawesi \\ Province in Completion of Litigational Case in Regional Government
}

\author{
Markus Iman Sucipto \\ Biro Hukum Setda Prov. Sultra \\ E-mail: markussucipto@gmail.com \\ Guasman Tatawu \\ Pascasarjana Universitas Halu Oleo \\ E-mail: gtatawu@gmail.com \\ Muhammad Sabaruddin Sinapoy \\ Pascasarjana Universitas Halu Oleo \\ E-mail: sabaruddinsinapoy@yahoo.com
}

\begin{abstract}
The type of research used in this study is normative legal research. Normative legal research is a process of finding legal rules, legal principles, and legal doctrines in order to answer legal issues faced which produce new arguments, theories and concepts as prescriptions in solving problems faced. By using a statutory approach, and conceptual approach.

In implementing government policies in the regions, it does not rule out the possibility of lawsuits arising from the Regional Heads, Regional Work Units and government institutions under them arising from the private sector, the community and individuals. With the existence of these legal cases there needs to be comprehensive handling of dispute resolution both in court and outside the court. The legal case referred to covers litigation and non-litigation cases. The notion of litigation is the resolution of legal issues that are handled and resolved through the judicial institution. Whereas Non-Litigation is the resolution of legal problems that are handled and resolved outside the judiciary.

Law Number 23 of 2014 concerning Regional Government in Article 65 paragraph (1) letter e states that the Regional Head represents his area inside and outside the court, and can appoint a legal representative to represent him in accordance with the laws and regulations. The attorney here can be authorized by the regional government attorney (PNSS/ASN) in the bureau / legal department, prosecutor's office or advocate based on Law Number 18 of 2003 concerning Advocates. Whereas between the attorney of the regional government and an advocate has a different
\end{abstract}


role in which Civil Servants act as elements of the State Civil Apparatus, while Advocates are acting as people who provide legal services to those who need their assistance.

Keyword: Authority of the Bureau of Law; Settlement; Litigation

Abstrak: Adapun jenis penelitian yang gunakan dalam penelitian ini adalah penelitian hukum normatif. Penelitian hukum normatif merupakan suatu proses untuk menemukan aturan hukum, prinsip-prinsip hukum, maupun doktrin-doktrin hukum guna menjawab isu hukum yang dihadapi yang menghasilkan argumentasi, teori dan konsep baru sebagai preskripsi dalam menyelesaikan masalah yang dihadapi. Dengan menggunakan pendekatan perundang-undangan (statute approach), dan konseptual (conseptual approach).

Dalam pelaksanaan kebijakan pemerintahan didaerah tidak menutup kemungkinan timbulnya gugatan perkara hukum yang ditujukan kepada Kepala Daerah, Satuan Kerja Perangkat Daerah dan lembaga pemerintahan di bawahnya yang timbul dari pihak swasta, masyarakat maupun perorangan. Dengan adanya perkara hukum tersebut perlu adanya penanganan secara komprehensif untuk penyelesaian sengketa baik di Pengadilan ataupun di luar pengadilan. Perkara hukum dimaksud meliputi perkara litigasi dan non litigasi. Adapun pengertian litigasi adalah penyelesaian permasalahan hukum yang ditangani dan diselesaikan melalui lembaga peradilan. Sedangkan Non Litigasi adalah penyelesaian permasalahan hukum yang ditangani dan diselesaikan di luar lembaga peradilan.

Undang-undang Nomor 23 tahun 2014 tentang Pemerintahan Daerah pada Pasal 65 ayat (1) huruf e disebutkan bahwa Kepala Daerah mewakili daerahnya di dalam dan di luar pengadilan, dan dapat menunjuk kuasa hukum untuk mewakilinya sesuai dengan peraturan perundang-undangan. Kuasa hukum di sini dapat dikuasakan kepada kuasa hukum pemerintah daerah (PNSS/ASN) pada biro/bagian hukum, kejaksaan, ataupun advokat berdasarkan UU Nomor 18 tahun 2003 tentang Advokat. Bahwa antara kuasa hukum pemerintah daerah dengan advokat mempunyai peranan yang berbeda dimana Pegawai Negeri Sipil berperan sebagai unsur Aparatur Sipil Negara, sedangkan Advokat adalah berperan sebagai orang yang berprofesi memberi jasa hukum kepada pihak yang memerlukan bantuannya.

Kata kunci: Kewenangan Biro Hukum; Penyelesaian; Litigasi

\section{PENDAHULUAN}

Plato mengemukakan bahwa penyelenggaraan negara yang baik ialah yang didasarkan pada pengaturan (hukum) yang baik. ${ }^{1}$ Salah satu ciri negara hukum; the rule of law ataupun rechtsstaat adalah adanya pembatasan atau pembagian kekuasaan dalam penyelenggaraan kekuasaan negara. ${ }^{2}$ Terkait dengan penyelenggaraan kekuasaan negara di Indonesia terbagi dalam dua kekuasaan pemerintahan, yaitu kekuasaan Pemerintah Pusat dan Pemerintah Daerah. ${ }^{3}$

Pembagian kekuasaan antara Pemerintah Pusat dan Pemerintah Daerah dilakukan dengan melimpahkan sebagian urusan Pemerintahan Pusat kepada Pemerintah Daerah.

Ni'matul Huda, Negara Hukum, Demokrasi dan Judicial Review, Yogyakarta: UII Press, 2005, hlm. 1.

Majda El. Muhtaj, Hak Asasi Manusia dalam Konstitusi Indonesia, Jakarta: Kencana, 2005, hlm. 1.

3 Moh. Kusnardi, Hukum Tata Negara Indonesia, Jakarta: Sinar Bakti, 1987, hlm. 153. 
Secara konstitusional, pembagian kekuasaan tersebut dirumuskan pada Pasal 18 UndangUndang Dasar Negara Republik Indonesia Tahun 1945 (selanjutnya disingkat UUD NRI Tahun 1945) yang menyatakan Negara Kesatuan Republik Indonesia dibagi atas daerahdaerah provinsi dan daerah provinsi dibagi pula atas kabupaten dan kota dan tiap-tiap provinsi, kabupaten, dan kota itu mempunyai pemerintahan daerah. ${ }^{4}$ Pembagian kekuasaan tersebut secara murni ditujukan untuk mempercepat pembangunan yang mengarah pada tercapainya kesejahteraan masyarakat secara merata dan adil. 5

Penyerahan otonomi daerah tersebut memberikan keleluasaan kepada pemerintah daerah untuk mengatur dan mengurus daerahnya secara mandiri dan bertanggungjawab sesuai dengan kebutuhan dan potensi daerah masing-masing. Salah satu kewenangan yang dimiliki oleh pemerintah daerah dalam menyelenggarakan urusan pemerintahan yaitu mengelola aset daerah yang dimiliki. Aset daerah merupakan sumber daya penting yang dimiliki pemerintah daerah sebagai sumber utama Pendapatan Asli Daerah (PAD). Oleh sebab itu, pemerintah daerah harus mampu mengelola aset daerahnya. Pengelolaan barang daerah sesuai dengan Peraturan Menteri Dalam Negeri Nomor 19 tahun 2016 tentang Pedoman Pengelolaan Barang Milik Daerah (selanjutnya disingkat Permendagri No.19/2016) meliputi perencanaan kebutuhan dan penganggaran, pengadaan, penggunaan, pemanfaatan, pengamanan dan pemeliharaan, penilaian, pemindahtanganan, pemusnahan, penghapusan, penatausahaan, pembinaan, pengawasan dan pengendalian.

Untuk menyelenggarakan suatu sistem pemerintahan yang baik, pemerintah daerah membentuk satuan kerja perangkat daerah yang memiliki tugas pokok dan fungsi sesuai bidang masing-masing. Peraturan Pemerintah Nomor 18 Tahun 2016 tentang Perangkat Daerah (selanjutnya disingkat PP No.18/2016) memberikan legitimasi kewenangan kepada Kepala Daerah untuk menetapkan susunan Perangkat Daerah melalui Peraturan Kepala Daerah. ${ }^{6}$

Guna membantu pelaksanaan tugas-tugas pemerintahan, berdasarkan PP No.18/2016, Pemerintah Daerah Provinsi Sulawesi Tenggara menetapkan perangkat daerah di lingkup sekretariat daerah Provinsi Sulawesi Tenggara. Berdasarkan Peraturan Gubernur Provinsi Sulawesi Tenggara Nomor 50 Tahun 2016 tentang Kedudukan, Susunan Organisasi, Tugas dan Fungsi Serta Tata Kerja Sekretariat Daerah Provinsi

\footnotetext{
Tahir Azhary, Negara Hukum, Jakarta: Kencana, 2010, hlm. 85-86.

Ridwan HR, Hukum Administrasi Negara, Jakarta: Raja Grafindo Persada, 2006, hlm. 2.

Philipus M. Hadjon, Perlindungan Hukum Bagi Rakyat di Indonesia, Surabaya: Bina Ilmu, 1987, hlm. 72.
} 
Sulawesi Tenggara (selanjutnya disingkat Pergub No.50/2016), Biro Hukum merupakan salah satu Perangkat Daerah yang memiliki tugas menyiapkan bahan penyusunan perumusan peraturan perundang-undangan, kajian dan evaluasi kebijakan daerah kabupaten/kota, peningkatan bantuan hukum dan Hak Asasi Manusia serta dokumentasi dan penyuluhan Hukum.

Undang-Udang Nomor 23 tahun 2014 tentang Pemerintahan Daerah Pasal 65 ayat (1) huruf e disebutkan bahwa Kepala Daerah mewakili daerahnya di dalam dan di luar pengadilan, dapat menunjuk kuasa hukum untuk mewakilinya sesuai dengan peraturan perundang-undangan. Kuasa hukum di sini dapat dikuasakan kepada kuasa hukum pemerintah daerah (PNS/ASN) pada biro/bagian hukum, kejaksaan, ataupun advokat berdasarkan Undang-Undang Nomor 18 tahun 2003 tentang Advokat. Bahwa antara kuasa hukum pemerintah daerah dengan advokat mempunyai peranan yang berbeda dimana Pegawai Negeri Sipil berperan sebagai unsur Aparatur Sipil Negara, sedangkan Advokat adalah berperan sebagai orang yang berprofesi memberi jasa hukum kepada pihak yang memerlukan bantuannya.

Pasal 6 ayat (3) Peraturan Menteri Dalam Negeri Nomor 12 Tahun 2014 tentang Pedoman Penanganan Perkara Di Lingkungan Kementerian Dalam Negeri Dan Pemerintah Daerah (selanjutnya disingkat Permendagri No.12/2014) mengatur bahwa Biro Hukum Provinsi dalam menangani perkara berkoordinasi dengan Biro Hukum Kementerian Dalam Negeri, Bagian Hukum Kabupaten/Kota dan SKPD terkait. Selain melaksanakan tugas pokok dan fungsi dalam menyelenggarakan pemerintahan daerah, Biro Hukum juga berfungsi sebagai kuasa hukum Pemerintah Daerah yang diberikan kuasa substitusi untuk mewakili Pemerintah Daerah untuk beracara di Pengadilan untuk kepentingan hukum Pemerintah Daerah dalam penanganan perkara.

Pemberian tugas kepada Biro Hukum sebagai kuasa hukum pemerintah daerah memang tidak lain dan tidak bukan untuk memberikan perlindungan hukum, termasuk melakukan penyelesaian sengketa baik di dalam maupun di luar pengadilan terhadap setiap kebijakan pemerintah yang dipersoalkan oleh pihak mana pun. Setiap kebijakan daerah, baik yang dilakukan oleh kepala daerah maupun perangkat daerah yang ada di bawahnya menjadi tugas keharusan biro hukum untuk menangani setiap gugatan yang ditujukan kepada pemerintah Daerah. Dalam hal pengelolaan aset daerah maupun dalam pelaksanaan tugas-tugas pemerintahan lainnya, kerap kali kebijakan-kebijakannya menjadi sumber lahirnya sengketa. 
Berdasarkan Permendagri No.12/2014, penanganan perkara litigasi dan non litigasi dilakukan oleh bagian hukum berdasarkan lingkup wilayah tugasnya yaitu Penanganan perkara hukum di lingkungan Kabupaten/Kota dilaksanakan Bagian Hukum Kabupaten/Kota di wilayahnya. Litigasi dimaksud terdiri atas: 1. Perkara Perdata; 2. Perkara Pidana; 3. Perkara Tata Usaha Negara; dan 4. Perkara di Badan Peradilan Lainnya.

Adanya sengketa yang muncul atas setiap kebijakan yang dilakukan oleh pemerintah daerah maupun perangkat yang ada di bawahnya menjadi kerugian tersendiri bagi pemerintah daerah. Untuk penyelesaian sengketa tersebut pemerintah daerah harus mengeluarkan energi dan materi yang tidak sedikit. Tidak hanya itu lemahnya koordinasi serta minimnya kualitas sumber daya manusia yang ada di internal Biro Hukum Sekretariat Daerah Provinsi Sulawesi Tenggara dapat mengakibatkan hapusnya hak kepemilikan atas aset-aset yang dimiliki oleh daerah ataupun produk hukum Kepala Daerah yang dinyatakan tidak sah.

Beberapa tahun terakhir ini pemerintah daerah Provinsi Sulawesi Tenggara acap kali menerima gugatan yang menyangkut pengelolaan aset-aset daerah dan gugatan terhadap Keputusan Tata Usaha Negara yang dikeluarkan oleh Pejabat Tata Usaha Negara dilingkup Pemerintah Provinsi Sulawesi Tenggara. Gugatan-gugatan tersebut mengakibatkan pemerintah daerah harus kehilangan aset-aset daerahnya dan batalnya Keputusan Tata Usaha Negara karena kalah dalam persidangan. Hilangnya aset-aset daerah dan batalnya Keputusan Tata Usaha Negara tentu menjadi catatan buruk terhadap kinerja Biro Hukum Sekretariat Daerah Provinsi Sulawesi Tenggara dalam menangani setiap persoalan hukum yang diterima oleh pemerintah daerah.

Atas pemikiran tersebut peneliti tertarik untuk menilai lebih jauh mengenai peran biro hukum dalam menyelesaikan sengketa yang ditujukan kepada pemerintah daerah dengan judul "Kewenangan Biro Hukum Sekretariat Daerah Provinsi Sulawesi Tenggara Dalam Penyelesaian Perkara Litigasi di Lingkungan Pemerintah Daerah". Berdasarkan dari uraian latar belakang di atas, maka penulis menarik permasalahan yaitu: (1). Bagaimanakah Kewenangan Biro Hukum Sekretariat Daerah Provinsi Sulawesi Tenggara Dalam Penyelesaian Perkara Litigasi di Lingkungan Pemerintah Daerah? dan (2). Apakah Biro Hukum Sekretariat Daerah Provinsi Sulawesi Tenggara Dapat Menjadi Kuasa Hukum Dalam Penyelesaian Perkara Litigasi di Lingkungan Pemerintah Daerah? 


\section{METODE PENELITIAN}

Jenis penelitian yang gunakan dalam penelitian ini adalah penelitian hukum normatif. Penelitian hukum normatif merupakan suatu proses untuk menemukan aturan hukum, prinsip-prinsip hukum, maupun doktrin-doktrin hukum guna menjawab isu hukum yang dihadapi yang menghasilkan argumentasi, teori dan konsep baru sebagai preskripsi dalam menyelesaikan masalah yang dihadapi. ${ }^{7}$ Adapun penelitian hukum (legal research) adalah menemukan kebenaran koherensi, yaitu adakah aturan hukum sesuai norma hukum dan adakah norma yang berupa perintah atau larangan itu sesuai dengan prinsip hukum, serta apakah tindakan (act) seseorang sesuai dengan norma hukum (bukan hanya sesuai aturan hukum) atau prinsip hukum. ${ }^{8}$

Penelitian hukum tidak dikenal adanya data. Oleh karena itu, untuk memecahkan isu hukum dan sekaligus memberikan preskripsi mengenai apa yang seyogyanya. Maka, diperlukan sumber-sumber penelitian. Sumber-sumber penelitian dapat dibedakan menjadi sumber-sumber penelitian yang berupa bahan-bahan hukum primer dan bahanbahan hukum sekunder.

\section{ANALISIS DAN PEMBAHASAN}

\section{Kewenangan Biro Hukum Sekretariat Daerah Provinsi Sulawesi Tenggara Dalam Penyelesaian Perkara Litigasi di Lingkungan Pemerintah Daerah}

Perkembangan konsep negara hukum mengalami perumusan yang berbeda-beda. ${ }^{9}$ Begitu juga dengan Bangsa Indonesia adalah bangsa yang majemuk, terdiri dari berbagai suku bangsa, agama dan bahasa. ${ }^{10}$ Sehingga, pemikiran atau konsepsi manusia merupakan anak zaman yang lahir dan berkembang dalam situasi kesejarahan dengan berbagai pengaruhnya. Pemikiran atau konsepsi manusia tentang negara hukum juga lahir dan berkembang dalam situasi kesejarahan. Oleh karena itu, meskipun konsep negara hukum dianggap sebagai konsep universal, pada dataran implementasi ternyata memiliki karakteristik beragam. Hal ini dikarenakan adanya pengaruh-pengaruh situasi kesejarahan, di samping pengaruh falsafah bangsa, ideologi negara, dan lain-lain. Salah

\footnotetext{
Peter Mahmud Marzuki, Penelitian Hukum, Jakarta: Prenada Media Group, 2011, hlm. 35.

Ibid., hlm. 47.

Rozikin Daman, Hukum Tata Negara, Jakarta: Raja Grafindo Persada, 1993, hlm. 167.

10 Muh. Sabaruddin Sinapoy, Kearifan Lokal Masyarakat Adat Suku Moronene dalam Perlindungan dan Pengelolaan Lingkungan Hidup, Halu Oleo Law Review, Volume 2 Issue 2, September 2018, http://ojs.uho.ac.id/index.php/holrev/article/view/4513, diakses pada tanggal 21 Mei 2019, hlm. 519.
} 
satu di antaranya mengenai konsep rechtsstaat bertumpu atas sistem Hukum Kontinental yang disebut civil law. Karakteristik civil law adalah administratif. ${ }^{11}$

Menurut Philipus M. Hadjon, konsep rechtsstaat lahir dari suatu perjuangan menentang absolutisme sehingga sifatnya revolusioner, sebaliknya konsep the rule of law berkembang secara evolusioner. Hal ini tampak baik dari isi maupun kriteria rechtsstaat dan rule of law itu sendiri. ${ }^{12}$ Konsep rechtsstaat bertumpu atas sistem hukum kontinental yang disebut civil law, sedangkan konsep the rule of law bertumpu atas sistem hukum yang disebut common law. Karakteristik civil law adalah administratif, sedangkan karakteristik common law adalah judicial. ${ }^{13}$ Oleh karena itu, pengertian pemerintah atau government dalam bahasa Indonesia berarti pengarahan dan administrasi yang berwenang atas kegiatan orang-orang dalam sebuah negara, negara bagian, atau kota dan sebagainya. Bisa juga berarti lembaga atau badan yang menyelenggarakan pemerintahan negara, negara bagian, atau kota, dan sebagainya.

Menurut W.S Sayre, pemerintah dalam definisi terbaiknya adalah sebagai organisasi dari negara yang memperlihatkan dan menjalankan kekuasaannya. Selanjutnya menurut David Apter (1977), pemerintah adalah satuan anggota yang paling umum yang memiliki tanggung jawab tertentu untuk mempertahankan sistem yang mencangkupnya dan monopoli praktis yang menyangkut kekuasaan paksaannya. ${ }^{14}$

Selanjutnya, daerah adalah lingkungan pemerintah: wilayah, daerah diartikan sebagai bagian permukaan bumi; lingkungan kerja pemerintah, wilayah; selingkup tempat yang dipakai untuk tujuan khusus, wilayah; tempat-tempat sekeliling atau yang dimaksud dalam lingkungan suatu kota; tempat yang terkena peristiwa sama; bagian permukaan tubuh. ${ }^{15}$ Lain halnya dengan C.F Strong yang menyebutkan bahwa pemerintahan daerah adalah organisasi dimana diletakkan hak untuk melaksanakan kekuasaan berdaulat atau tertinggi. Pemerintahan dalam arti luas merupakan sesuatu yang lebih besar daripada suatu badan atau kelompok. ${ }^{16}$

Pemerintah daerah yang merupakan sub-sistem dari sistem penyelenggaraan pemerintahan nasional memiliki kewenangan untuk mengatur dan mengurus rumah

11 Ni'matul Huda, Hukum Tata Negara Indonesia, Jakarta: Raja Grafindo Persada, 2006, hlm. 74.

Majda El. Muhtaj, Hak Asasi Manusia Dalam Konstitusi Indonesia, Jakarta: Kencana, 2005, hlm. 21.

3 Ni'matul Huda, Op. Cit, hlm. 74.

14 Inu Kencana Syafiie, Pengantar Ilmu Pemerintahan, Jakarta: Refika Aditama, 2010, hlm. 11.

15 G. Setya Nugraha, R. Maulina F, Kamus Besar Bahasa Indonesia, Surabaya: tanpa penerbit, hlm. 145.

16 Fahmi Amrusi dalam Ni'matull Huda, Hukum Pemerintah Daerah, Bandung: Nusamedia, 2012, hlm. 28. 
tangganya sendiri. Hal ini dalam pandangan Sarundajang mengatakan bahwa, otonomi atau autonomy berasal dari bahasa Yunani, auto berarti sendiri dan nomous yang berarti hukum atau peraturan. ${ }^{17}$ Tujuan pemberian otonomi kepada daerah adalah untuk memungkinkan daerah yang bersangkutan mengatur dan mengurus rumah tangganya sendiri untuk meningkatkan daya guna dan hasil guna penyelenggaraan pemerintah dalam rangka pelayanan terhadap masyarakat dan pelaksanaan pembangunan. Untuk melaksanakan tujuan tersebut, kepada daerah perlu diberikan kewenangan-kewenangan sebagai urusan rumah tangganya. ${ }^{18}$ Dalam implementasinya, kewenangan daerah termasuk dalam penyelesaian sengketa yang melibatkan pemerintah daerah dengan pihak ketiga. Penyelesaian sengketa dapat dilakukan melalui litigasi dan non litigasi.

Kewenangan untuk mengatur dan mengurus rumah tangga ini mengandung tiga hal utama di dalamnya, ${ }^{19}$ yaitu: pertama, Pemberian tugas dan wewenang untuk menyelesaikan suatu kewenangan yang sudah diserahkan kepada Pemerintah Daerah; kedua, Pemberian kepercayaan dan wewenang untuk memikirkan, mengambil inisiatif dan menetapkan sendiri cara-cara penyelesaian tugas tersebut; dan ketiga, dalam upaya memikirkan, mengambil inisiatif dan mengambil keputusan tersebut mengikutsertakan masyarakat baik secara langsung maupun DPRD.

Bilamana merujuk kepada ketentuan Pasal 65 ayat (1) huruf e UU No. 23 Tahun 2014 disebutkan bahwa kepala daerah mewakili daerahnya di dalam dan di luar pengadilan, dan dapat menunjuk kuasa hukum untuk mewakilinya sesuai dengan peraturan perundang-undangan. Maka, dalam rangka keseragaman dan ketertiban dalam penanganan perkara di lingkungan pemerintah daerah telah ditetapkan Permendagri No. 12 Tahun 2014 sebagai dasar hukum dan standarisasi metode penyelesaian permasalahan sengketa hukum, dimana penanganan perkara sengketa hukum antara pemerintah daerah dengan pihak ketiga dilakukan oleh Bagian Hukum berdasarkan lingkup wilayah tugasnya.

17 Muslimin Nasution, Pokok-Pokok Kebijaksanaan Pengelolaan Sumber Daya Alam Kehutanan Dalam Rangka Otonomi Daerah, Makalah Seminar, Yogyakarta, 21 September 1999, hlm. 2.

18 Soenyono, Prospek Pelaksanaan Otonomi Daerah Berdasarkan UU No. 22 Tahun 1999 tentang Pemerintahan Daerah, dalam Andi A. Malarangeng, (et.al), Otonomi Daerah Perspektif Teoritis dan Praktis, Cet. Pertama, Yogyakarta: Bigraf Publishing, 2001, hlm. 107.

19 Setya Retnami, Makalah Sistem Pemerintahan Daerah di Indonesia, Jakarta: Kantor Menteri Negara Otonomi Daerah Republik Indonesia, 2001, hlm. 8. 


\section{Kedudukan Biro Hukum Sekretariat Daerah Provinsi Sulawesi Tenggara Sebagai Kuasa Hukum Dalam Penyelesaian Perkara Litigasi di Lingkungan Pemerintah Daerah}

Pelaksanaan kebijakan pemerintahan daerah tidak menutup kemungkinan timbulnya gugatan perkara hukum yang ditujukan kepada pemerintah daerah dalam hal ini kepala daerah atau perangkat daerah yang timbul dari pihak ketiga yaitu pihak swasta, masyarakat maupun perorangan. Dengan adanya perkara hukum tersebut memerlukan penanganan untuk penyelesaian sengketa. Melalui ketentuan Pasal 65 ayat (1) huruf e UU No. 23 Tahun 2014 disebutkan bahwa kepala daerah mewakili daerahnya di dalam dan di luar pengadilan, dan dapat menunjuk kuasa hukum untuk mewakilinya sesuai dengan peraturan perundang-undangan. Dari ketentuan tersebut yang berhak mewakili daerah baik di dalam maupun di luar pengadilan adalah Gubernur, namun Gubernur dapat menunjuk kuasa hukum untuk mewakilinya.

Secara umum, dalam UU No. 18 Tahun 2003 tentang Advokat dijelaskan bahwa kuasa hukum adalah advokat. Selanjutnya, dalam Pasal 3 ayat (1) huruf c UU Advokat disebutkan salah satu syarat seseorang untuk dapat diangkat menjadi advokat adalah tidak berstatus sebagai pegawai negeri atau pejabat negara. Kemudian dalam UU No. 16 Tahun 2004 tentang Kejaksaan Republik Indonesia Pasal 30 ayat (2) disebutkan bahwa Jaksa sebagai pegawai negeri sipil (PNS) dapat menjadi kuasa hukum di pengadilan. Dengan kata lain, Jaksa dengan kuasa khusus dapat menjadi kuasa hukum dari Negara Republik Indonesia atau Pemerintah Republik Indonesia dalam hal negara atau pemerintah menjadi pihak dalam perkara perdata atau tata usaha negara.

Selain Jaksa sebagaimana disebutkan dalam Pasal 30 ayat (2) UU Kejaksaan, Pegawai Negeri Sipil yang juga dapat menjadi kuasa hukum adalah Biro Hukum Pemerintah atau orang tertentu yang ditunjuk oleh instansi yang bersangkutan. Seperti disebutkan dalam buku Pedoman Pelaksanaan Tugas dan Administrasi Pengadilan Buku II tahun 2004 bahwa Kuasa/Wakil Negara/Pemerintah dalam suatu perkara perdata berdasarkan Staatsblad 1922 No.522 dan Pasal 123 ayat (2) HIR. Jadi, pegawai negeri sipil yang dapat menjadi kuasa hukum di pengadilan adalah Jaksa yang diberi kuasa khusus untuk mewakili negara atau pemerintah dalam perkara di bidang perdata atau tata usaha negara atau Biro Hukum Pemerintah di Bidang Perdata dan Tata Usaha Negara.

Berdasarkan Peraturan Daerah Provinsi Sulawesi Tenggara Nomor 13 Tahun 2016 Biro Hukum merupakan perangkat daerah yang berada di Sekretariat Daerah Provinsi 
Sulawesi Tenggara, yang memiliki uraian tugas pokok dan fungsinya diatur dalam Peraturan Gubernur Sulawesi Tenggara Nomor 50 Tahun 2016 tentang Tugas Pokok dan Fungsi Organisasi Perangkat Daerah Lingkup Pemerintah Provinsi Sulawesi Tenggara (Pergub Sulawesi Tenggara No. 50 Tahun 2016).

Setiap organisasi pemerintahan, tugas pokok dan fungsi merupakan bagian tidak terpisahkan dari keberadaan organisasi tersebut. Penetapan tugas pokok dan fungsi atas suatu organisasi menjadi landasan hukum unit organisasi tersebut dalam beraktivitas sekaligus sebagai rambu-rambu dalam pelaksanaan tugas dan koordinasi pada tataran aplikasi di lapangan. Tugas pokok dan fungsi secara umum merupakan hal-hal yang harus bahkan wajib dikerjakan oleh seorang anggota organisasi atau pegawai dalam suatu instansi secara rutin sesuai dengan kemampuan yang dimilikinya untuk menyelesaikan program kerja yang telah dibuat berdasarkan tujuan, visi dan misi suatu organisasi. Setiap pegawai seharusnya melaksanakan kegiatan yang lebih rinci yang dilaksanakan secara jelas dan dalam setiap bagian atau unit. Rincian tugas-tugas tersebut digolongkan ke dalam satuan praktis dan konkret sesuai dengan kemampuan dan tuntutan masyarakat. Tugas pokok dan fungsi merupakan suatu kesatuan yang saling terkait antara tugas pokok dan fungsi. Suatu organisasi menyelenggarakan fungsi-fungsi dalam melaksanakan tugas pokok. Tugas pokok adalah suatu kewajiban yang harus dikerjakan, pekerjaan yang merupakan tanggung jawab, perintah untuk berbuat atau melakukan sesuatu demi mencapai suatu tujuan. Tugas pokok sebagai satu kesatuan pekerjaan atau kegiatan yang paling utama dan rutin dilakukan oleh para pegawai dalam sebuah organisasi yang memberikan gambaran tentang ruang lingkup atau kompleksitas jabatan atau organisasi demi mencapai tujuan tertentu. ${ }^{20}$

Penyelenggaraan pemerintahan daerah di lingkup Pemerintah Provinsi Sulawesi Tenggara, berdasarkan Peraturan Gubernur Sulawesi Tenggara Nomor 50 Tahun 2016, Biro Hukum mempunyai tugas pokok mengkaji bahan kebijakan umum dan penyelenggaraan perumusan perundang-undangan, bantuan hukum dan hak asasi manusia serta pengembangan hukum. Untuk melaksanakan tugas pokok tersebut Biro Hukum Pemerintah Provinsi Sulawesi Tenggara menyelenggarakan fungsi:1. Pengkajian bahan kebijakan umum di bidang penataan hukum; 2. Penyelenggaraan koordinasi perumusan perundang-undangan; 3. Penyelenggaraan koordinasi bantuan hukum; 4.

20 Muammar Himawan, Pokok-Pokok Organisasi Modern, Jakarta: Bina Ilmu, 2004, hlm. 38. 
Penyelenggaraan koordinasi pengembangan hukum; dan 5. Fasilitasi perumusan peraturan perundang-undangan kabupaten/kota. Juga ditegaskan berdasarkan Peraturan Menteri Dalam Negeri Nomor 12 Tahun 2014, bahwa penanganan perkara litigasi dan non litigasi dilakukan oleh Bagian Hukum berdasarkan lingkup wilayah tugasnya, yaitu penanganan perkara hukum di lingkungan provinsi atau kabupaten /kota. Perkara yang dimaksud terdiri atas: 1. Perkara perdata; 2. Perkara Pidana; 3. Perkara Tata Usaha Negara; dan 4. Perkara di badan peradilan lain.

\section{KESIMPULAN}

Berdasarkan uraian di atas, maka yang menjadi kesimpulan dalam tulisan jurnal ini sebagai berikut:

1. Pemberian kewenangan pemerintah daerah untuk menyelenggarakan pemerintahannya yang disebut desentralisasi kepada daerah-daerah otonom (otonomi daerah), sebagai tujuan daripada bangsa Indonesia adalah membentuk masyarakat adil dan makmur berdasarkan Pancasila. Desentralisasi memiliki dua bentuk yaitu politik dan administratif. Kewenangannya mulai dari penetapan peraturan sampai keputusan substansial yang bersumber dari peraturan perundang-undangan melalui atributi, delegasi dan mandat. Pembentuk undang-undang menentukan suatu organ pemerintahan berikut wewenangnya baik kepada organ yang sudah ada maupun baru dibentuk, merujuk pada ketentuan Pasal 65 ayat (1) huruf e UU No. 23 Tahun 2014 serta melalui Permendagri No. 12 Tahun 2014.

2. Pelaksanaan kewenangan Biro Hukum dalam menangani perkara sengketa hukum berdasarkan pada tugas pokok dan fungsinya sebagai perangkat daerah yang telah diatur dalam Peraturan Daerah Provinsi Sulawesi Tenggara Nomor 13 Tahun 2016 dan Peraturan Gubernur Sulawesi Tenggara Nomor 50 Tahun 2016. Sedangkan standardisasi pelaksanaan tugas pokok dan fungsi dalam penanganan perkara sengketa hukum dilakukan sesuai ketentuan Permendagri No. 12 Tahun 2014.

\section{Daftar Pustaka}

\section{Buku}

Azhary, Tahir, Negara Hukum, Jakarta: Kencana, 2010. 
Daman, Rozikin, Hukum Tata Negara, Jakarta: Raja Grafindo Persada, 1993.

Hadjon, Philipus M., Perlindungan Hukum Bagi Rakyat di Indonesia, Surabaya: Bina Ilmu, 1987.

Himawan, Muammar, Pokok-Pokok Organisasi Modern, Jakarta: Bina Ilmu, 2004.

HR, Ridwan, Hukum Administrasi Negara, Jakarta: Raja Grafindo Persada, 2006.

Huda, Ni'matul, Hukum Tata Negara Indonesia, Jakarta: Raja Grafindo Persada, 2006.

Huda, Ni'matul, Negara Hukum, Demokrasi dan Judicial Review, Yogyakarta: UII Press, 2005.

Huda, Ni'matull, Hukum Pemerintah Daerah, Bandung: Nusamedia, 2012.

Kusnardi, Moh., Hukum Tata Negara Indonesia, Jakarta: Sinar Bakti, 1987.

Malarangeng, Andi A., et.al, Otonomi Daerah Perspektif Teoritis dan Praktis, Cet. Pertama, Yogyakarta: Bigraf Publishing, 2001.

Marzuki, Peter Mahmud, Penelitian Hukum, Jakarta: Prenada Media Group, 2011.

Muhtaj, Majda El., Hak Asasi Manusia dalam Konstitusi Indonesia, Jakarta: Kencana, 2005.

Nasution, Muslimin, Pokok-Pokok Kebijaksanaan Pengelolaan Sumber Daya Alam Kehutanan Dalam Rangka Otonomi Daerah, Makalah Seminar, Yogyakarta, 21 September 1999.

Nugraha, G. Setya, R. Maulina F, Kamus Besar Bahasa Indonesia, Surabaya: tanpa penerbit. Retnami, Setya, Makalah Sistem Pemerintahan Daerah di Indonesia, Jakarta: Kantor Menteri Negara Otonomi Daerah Republik Indonesia, 2001.

Syafiie, Inu Kencana, Pengantar Ilmu Pemerintahan, Jakarta: Refika Aditama, 2010, hlm. 11.

\section{Peraturan Perundang-undangan}

Undang-Undang Dasar Negara Republik Indonesia 1945

Undang-Undang Nomor 14 Tahun 1970 Tentang Ketentuan Pokok Kekuasaan Kehakiman Undang-Undang Nomor 30 Tahun 1999 Tentang Arbitrase dan Alternatif Penyelesaian Sengketa.

Undang-Undang Nomor 43 Tahun 1999 Tentang Perubahan Undang-Undang Nomor 8 Tahun 1974 tentang Pokok-pokok Kepegawaian.

Undang-Undang Nomor 18 Tahun 2003 Tentang Advokat.

Undang-Undang Nomor 16 Tahun 2004 Tentang Kejaksaan Republik Indonesia.

Undang-Undang Nomor 12 Tahun 2011 sebagaimana diubah dari Undang-Undang Nomor

10 Tahun 2004 Tentang Pembentukan Peraturan Perundang-Undangan 
Undang-Undang Nomor 23 Tahun 2014 Tentang Pemerintahan Daerah

Peraturan Pemerintah Nomor 18 Tahun 2016 tentang Perangkat Daerah

Peraturan Daerah Provinsi Sulawesi Tenggara Nomor 13 Tahun 2016 Tentang Pembentukan Perangkat Daerah Di Lingkungan Pemerintah Provinsi Sulawesi Tenggara.

Peraturan Mahkamah Agung Nomor 1 Tahun 2008 Tentang Prosedur Mediasi di Pengadilan.

Peraturan Menteri Dalam Negeri Nomor 12 Tahun 2014 tentang Pedoman Penanganan Perkara Di Lingkungan Kementerian Dalam Negeri Dan Pemerintah Daerah

Peraturan Menteri Dalam Negeri Nomor 19 tahun 2016 tentang Pedoman Pengelolaan Barang Milik Daerah

Peraturan Gubernur Sulawesi Tenggara Nomor 50 Tahun 2016 Tentang Tugas Pokok dan Fungsi Organisasi Perangkat Daerah Lingkup Pemerintah Provinsi Sulawesi Tenggara.

\section{e-Journal}

Sinapoy, Muh. Sabaruddin, Kearifan Lokal Masyarakat Adat Suku Moronene dalam Perlindungan dan Pengelolaan Lingkungan Hidup, Halu Oleo Law Review, Volume 2 Issue 2, September 2018, http://ojs.uho.ac.id/index.php/holrev/article/view/4513, diakses pada tanggal 21 Mei 2019. 